\title{
Can Iberian red deer (Cervus elaphus hispanicus) discriminate among essential minerals in their diet?
}

\author{
Francisco Ceacero $^{1,2,3 *}$, Tomás Landete-Castillejos ${ }^{1,2,3}$, Andrés J. García ${ }^{1,2,3}$, José A. Estévez ${ }^{1,2,3,4}$ \\ and Laureano Gallego ${ }^{1}$ \\ ${ }^{1}$ Departamento de Ciencia y Tecnología Agroforestal y Genética, ETSIA, Universidad de Castilla-La Mancha, 02071 Albacete, \\ Spain \\ ${ }^{2}$ Sección de Recursos Cinegéticos, IDR, Universidad de Castilla-La Mancha, 02071 Albacete, Spain \\ ${ }^{3}$ Animal Science Techniques Applied to Wildlife Management Research Group, IREC Section Albacete, Campus UCLM, 02071 \\ Albacete, Spain \\ ${ }^{4}$ Venadogen S.L., Avenida de la Innovación 1, 02071 Albacete, Spain
}

(Received 22 April 2009 - Revised 10 August 2009 - Accepted 19 August 2009 - First published online 28 October 2009)

Optimal foraging predicts that animals should be able to assess the content of important nutrients in food. Ungulates discriminate salt and P, but discrimination of other minerals is controversial even though they are also essential and often limiting. Animal scientists have explained this taste through palatability, which predicts the same pattern of discrimination for calves and hinds and greater consumption by the latter. Social learning may also be involved, predicting a correlation between mother and calf and less consumption by the latter. The present study examines the consumption behaviour of free-choice supplemented minerals by hinds and calves of Iberian red deer (Cervus elaphus hispanicus) to discern between these hypotheses. Behavioural indices of intake correlated with actual mineral consumption $(P<0 \cdot 001)$. Mother and calf behavioural indices correlated only for salt-mixed minerals. Calves showed overall behavioural indices of consumption greater than hinds $(P<0.01$ and $P<0.001)$, and also for all single supplements except $\mathrm{NaCl}$, as expected from growth needs and in contrast to the palatability hypothesis. Calves showed a greater consumption of $\mathrm{CuSO}_{4}$ and lower of $\mathrm{Na}_{2} \mathrm{SeO}_{3}$ than pure salt. Hinds showed a different pattern, ingesting lower amounts of all minerals except $\mathrm{CuSO}_{4}$ and salt. Additional analyses also showed discrimination between minerals unmixed with salt, such as $\mathrm{CaHPO}_{4}$ and $\mathrm{CaCO}_{3}$ $(P=0.012$ and $P=0.020)$. The greater intake of growing calves and the different consumption patterns for hinds and calves suggest that deer can discriminate among minerals, and that they do not consume minerals for their palatability or driven by social learning. Therefore, deer may be selecting minerals according to nutritional requirements.

Conditioned learning: Diet selection: Free choice: Mineral supplements: Palatability

Optimal foraging theory ${ }^{(1-3)}$ predicts the role of food quality in determining the diet composition and foraging tactics of animals. In the case of herbivores, this happens mainly by optimising energy intake and protein ${ }^{(4,5)}$, but also nutritional value $^{(6,7)}$, macronutrients ${ }^{(8)}$, maximising digestion rate ${ }^{(9)}$, and even avoiding poisonous toxins and tannins that reduce the digestibility of plant material ${ }^{(3,10)}$. However, balanced nutrition is a very complex process which requires an adequate intake of minerals, vitamins and other nutrients ${ }^{(11)}$. Thus, diets of freeranging ungulates are usually much more varied than ecologists predict on the basis of this theory ${ }^{(7)}$, and this implies that when animals behave as optimal foragers they should be able to assess the content of the most important nutrients in food. Among others, the most essential minerals should also be assessed on this basis, and ingested to meet threshold amounts.

All mammals have the ability to taste salt, and since Belovsky $^{(12)}$ explained diet selection of moose (Alces alces) by energy and $\mathrm{Na}$ balance, many behavioural studies have focused on $\mathrm{Na}$ intake, as this is one of the most limiting minerals for ungulates in natural habitats ${ }^{(13,14)}$. However, many other minerals are also essential and limiting in nature, and in fact they are usually supplemented in ruminant livestock $^{(15,16)}$. McNaughton ${ }^{(17,18)}$ even explained the distribution and migration of African ungulates based on $\mathrm{Na}$ availability in pastures, but also pointed out a possible influence of other minerals such as $\mathrm{Al}, \mathrm{Ca}, \mathrm{Fe}, \mathrm{Mg}$ and $\mathrm{P}$. Thereafter, several studies have suggested that different ungulate species were actively seeking for different minerals such as $\mathrm{Ca}, \mathrm{Mg}$ or $\mathrm{P}$ under different situations such as free-choice cafeteriastyle experiments, use of soil licks or analysis of forage mineral composition ${ }^{(19-22)}$. As optimal foraging theory assumes, many of these studies ${ }^{(15,17,18,22,23)}$ suggested or showed that patterns found were related to diet deficiencies ('specific hungers' or 'nutritional wisdom' hypothesis ${ }^{(24)}$,

Abbreviation: GLM, general linear model.

* Corresponding author: Dr Francisco Ceacero, fax +34967599233, email francisco.ceacero@uclm.es 
also proposed for trace minerals and ungulates ${ }^{(25)}$, but in fact a corollary of foraging theory as mentioned above). Our own previous results in red deer (Cervus elaphus hispanicus) showed specific intakes of $\mathrm{Na}$ and $\mathrm{Co}$ in relation to their content in food ${ }^{(26)}$. Thus, evidence reported suggests that ungulates have evolved the ability to detect $\mathrm{Na}$ and the major minerals forming vertebrate bodies $\left(\mathrm{Ca}\right.$ and $\left.\mathrm{P}^{(27)}\right)$. In contrast, there seems to be little evidence whether ungulates can detect and consume other minor but essential minerals.

The optimal foraging approach as a general rule has been criticised (particularly in the case of minerals) by animal scientists arguing that with such variety of nutrients (amino acids, vitamins, minerals, etc) and toxins, it seems unlikely that evolution has equipped animals with a specific appetite for each one ${ }^{(15,28-32)}$. They have proposed that 'conditioned food learning' is the most important mechanism by which herbivores optimise food selection of some nutrients and toxins by learning about the negative and positive consequences of consuming particular plant species through a series of encounters (post-ingestive cues ${ }^{(33-35)}$ ). Thus, by having this mechanism, animals would not need an innate ability to assess each specific nutrient. Negative conditioning has been repeatedly shown in ruminants under experimen$\operatorname{tal}^{(36-39)}$ and natural conditions ${ }^{(40)}$, but hardly for positive conditioning as would be required to study mineral intake ${ }^{(41)}$ (but see Ginane et al. ${ }^{(42)}$ and Sclafani ${ }^{(43)}$ for negative results), and neither for experiments with multiple foods similar to free-ranging conditions ${ }^{(3,44-46)}$. Thus, conditioned learning assumptions seem unlikely to be met in the complex ruminant diets proposed by optimal foraging theory ${ }^{(47-49)}$. Moreover, conditioned learning seems unlikely for minerals because they are needed from the earliest stages of life (thus, there should be some 'innate predispositions, $\left.{ }^{(35,50)}\right)$, and the remarkable effect they have on growth ${ }^{(16,51)}$ suggests that mammals are unlikely to afford the amount of time required for such learning. In addition, conditioned learning effects depend on relative deficiency, ranging from increasing positive effects with increasing intake under deficiency, to neutral effects when requirements are met, and finally, increasing negative effects with increasing intake when toxicity thresholds are exceeded. On the other hand, the nutritive value of a particular mineral content in a plant or food source depends on the amounts of the same or other minerals present in other plants or food sources consumed simultaneously, as the intake of some minerals reduces the absorption of others, causing their deficiency ${ }^{(16)}$. Thus, the complex interactions between intakes of specific minerals in a food source may have positive effects on some occasions, but neutral or even negative effects on other ones depending on the rest of the food items consumed at the same time.

Another factor involved in food selection is taste, which has evolved to evaluate some parameters of food such as salinity, energy, toxins and maybe proteins ${ }^{(52)}$, creating 'innate predispositions' widely accepted for many nutrients ${ }^{(35)}$. Thus, taste is another mechanism involved in consumption of mineral supplements in such a way that ruminants may even die before consuming an unpalatable mineral source ${ }^{(15,53)}$. The prediction derived from this hypothesis is a great intake of a palatable taste regardless of its beneficial effect ${ }^{(54,55)}$.

Finally, the process of food selection according to the nutritive value of the diet components may be influenced by social learning. This term indicates a higher probability that an animal eats a certain food if it sees another one consuming it, or smells such food from the mouth of another ${ }^{(56)}$. This may be particularly interesting in our setting, as calves may learn from the behaviour of their mothers, being more likely to taste those minerals that their mothers consume and being more reluctant to eat even necessary minerals that their mothers do not consume.

The aim of the present paper was to examine taste $v$. social learning $v$. selective intake predicted by the optimal foraging hypothesis through the consumption behaviour of free-choice supplemented minerals by lactating hinds of Iberian red deer and their calves, with an experimental design to assess if deer can discriminate between minerals. As positive conditioning seems unlikely to explain mineral nutrition by ruminants, free-choice consumption of salt-mixed mineral supplements can only be driven by optimal foraging or by palatability. Common salt, because of its palatability, is a valuable carrier of unpalatable minerals when mixtures contain $30-40 \%$ salt or more ${ }^{(15)}$. We predicted that if deer discriminate among salt-mixed macro- and microminerals, they should show different consumption patterns. Under the palatability hypothesis they should show similar consumption patterns among all salt-mixed mineral supplements. Finally, under social learning calves should show similar patterns to their mothers, but less consumption shaped to their different weight. We also predict a greater consumption by calves if they behave as optimal foragers because they have greater requirements than hinds, whereas consumption should be greater for hinds if intake is predicted by palatability because of their larger bodies.

\section{Materials and methods}

The present study was carried out at the Experimental Farm of Universidad de Castilla-La Mancha (Albacete, Spain), under similar conditions as described by Landete-Castillejos et al. ${ }^{(57)}$. The experiments were performed during the 2005 and 2006 lactation season involving adult red deer hinds aged between 2 and 12 years old. All animals used were reared in captivity. During the first year, we used thirty-six hinds and their calves, and in the second year twenty-three different hinds and their calves. None of the hinds calved twins in those years. Study animals were kept captive in $10000 \mathrm{~m}^{2}$ enclosures without pasture. Both during gestation and throughout lactation, animals were fed with diets based on suggestions by Brelurut et al. ${ }^{(58)}$, using barley straw and hay from barley, lucerne, oat and sweet beetroot (16\% protein). Deer had ad libitum access to food and water. Calving took place during the months of May and June. Calves were weighed on their first $24 \mathrm{~h}$ of life and marked with ear tags (Allflex GTLF1, $76 \times 57 \mathrm{~mm}$; Allflex USA, Inc., DFW Airport, TX, USA). After 1 week, when calves started to be active all day, they were marked with ovine-livestock collars (Felixcan $00015,655 \times 59 \times 12 \mathrm{~mm}$; Flexican, Albacete, Spain), the same as hinds, so that all individuals could be identified from a distance. All enclosures were connected to handling premises by a $5 \mathrm{~m}$ wide corridor, where animals were weighed once per week on $\mathrm{a} \pm 50 \mathrm{~g}$ electronic balance. Calves up to $35 \mathrm{~kg}$ body weight were measured on $\mathrm{a} \pm 5 \mathrm{~g}$ balance and on the same balance as their mothers thereafter. 
Table 1. Empirical formulas, mineral concentration and source of minerals supplemented

\begin{tabular}{|c|c|c|c|c|c|}
\hline Chemical element & Supplement & Empirical formula & Offering format & Mineral concentration & Element content in diet ${ }^{*}$ \\
\hline $\mathrm{Ca}$ & Calcium carbonate & $\mathrm{CaCO}_{3}$ & Pure & $38.0 \% \mathrm{Ca}$ & $0.73 \%$ \\
\hline Co & Cobaltous sulfate & $\mathrm{CoSO}_{4} \cdot 7 \mathrm{H}_{2} \mathrm{O}$ & Mixed with $\mathrm{NaCl}$ at $7.5 \%$ & $1.6 \%$ Co & $0.03 \mathrm{ppm}$ \\
\hline $\mathrm{Cu}$ & Cupric sulfate & $\mathrm{CuSO}_{4} \cdot 5 \mathrm{H}_{2} \mathrm{O}$ & Mixed with $\mathrm{NaCl}$ at $7.5 \%$ & $1.9 \% \mathrm{Cu}$ & $16 \mathrm{ppm}$ \\
\hline $\mathrm{Fe}$ & Iron carbonate & $\mathrm{FeCO}_{3}$ & Pure & $38.0 \% \mathrm{Fe}$ & $230 \mathrm{ppm}$ \\
\hline 1 & Calcium iodate & $\mathrm{Ca}\left(\mathrm{IO}_{3}\right)_{2}$ & Mixed with $\mathrm{NaCl}$ at $7.5 \%$ & $4.7 \% 1$ & \\
\hline $\mathrm{K}$ & Potassium chloride & $\mathrm{KCl}$ & Pure & $52.3 \% \mathrm{~K}$ & $0.99 \%$ \\
\hline $\mathrm{Mg}$ & Magnesium oxide & $\mathrm{MgO}$ & Pure & $55.0 \% \mathrm{Mg}$ & $0.32 \%$ \\
\hline $\mathrm{Na}$ & Sodium chloride & $\mathrm{NaCl}$ & Pure & $40.0 \% \mathrm{Na}$ & $484 \mathrm{ppm}$ \\
\hline$P$ & Dicalcium phosphate & $\mathrm{CaHPO}_{4} \cdot 2 \mathrm{H}_{2} \mathrm{O}$ & Pure & $18.0 \% \mathrm{P} ; 23.0 \% \mathrm{Ca}$ & $0.45 \%$ \\
\hline Se & Sodium selenite & $\mathrm{Na}_{2} \mathrm{SeO}_{3}$ & Mixed with $\mathrm{NaCl}$ at $7.5 \%$ & $0.04 \% \mathrm{Se}$ & $13 \mathrm{ppm}$ \\
\hline $\mathrm{Zn}$ & Zinc sulfate & $\mathrm{ZnSO}_{4} \cdot \mathrm{H}_{2} \mathrm{O}$ & Mixed with $\mathrm{NaCl}$ at $20 \%$ & $7 \cdot 2 \% \mathrm{Zn}$ & $36 \mathrm{ppm}$ \\
\hline
\end{tabular}

ppm, Parts per million.

${ }^{*}$ Mineral content in diet was measured by atomic absorption spectrophotometry. lodine content in diet could not be detected.

One set of containers ( $30 \mathrm{~cm}$ wide; $50 \mathrm{~cm}$ long; $20 \mathrm{~cm}$ deep) with different minerals was offered lined up inside a shed which provided shelter from the wind and rain. Minerals were offered in chemical forms commonly used as animal supplements, and often selecting the alternative of highest bioavailability. This is defined as the proportion of the mineral which can be used by the animal to meet its bodily needs ${ }^{(15,59)}$. Minerals were offered in mixtures and concentrations recommended for ruminants ${ }^{(16,59,60)}$ (Table 1) and the position of the containers was randomly changed monthly to prevent confounding preference for a specific site with mineral discrimination. As trace minerals have toxic doses at low levels, and thus their presentation in pure form could risk accidental poisoning, they were offered mixed in with $\mathrm{NaCl}$ at concentrations trading detectability and safety. Animals could thus choose between pure $\mathrm{Na}$ and $\mathrm{Na}$ with $\mathrm{Co}, \mathrm{Cu}$, $\mathrm{Se}$, I or $\mathrm{Zn}$. Supplement consumption necessary to meet daily requirements of all salt-mixed minerals $(\mathrm{Co}, \mathrm{Cu}, \mathrm{Se}$, $\mathrm{Zn}$ and I) implies the ingestion of just $28 \%$ of $\mathrm{Na}$ daily requirements (calculated following available data on requirements $\left.{ }^{(16,61)}\right)$. That way, the ingestion of one mineral can be considered as independent of the ingestion of other minerals. Containers were weighed weekly with a Gram Precision AK Eagle $30( \pm 5 \mathrm{~g})$ portable scale (Gram Precision Scales, Inc., Mississauga, ON, Canada).

Behaviour of mineral consumption was recorded by two cameras installed inside the shed where minerals were offered. Cameras worked from 07.00 to 19.00 hours, from the first birth (middle May) up to weaning (middle September), and recording was buffered on a hard disk. Recordings showed every mineral intake event by each animal, its time length and the supplement consumed (containers were labelled both sides to be easily identified). As the exact amount of mineral swallowed by every animal could not be assessed, total consumption time (in s) and total number of intake visits were used as behavioural indices of consumption. Visits were considered only when jaw movement was observed, as animals used to sniff briefly different containers before eating. Other species (pigeons, rodents, etc) were seen to interact with the mineral containers.

As milk production requires large amounts of minerals ${ }^{(62)}$, we also assessed milk yield and its influence on mineral consumption by hinds. Hinds were milked under anaesthesia on weeks 2, 4, 6, 10, 14 and 18 of lactation, after $6 \mathrm{~h}$ isolation. Milking frequency was reduced to prevent stress and the potential damaging effects of the anaesthesia. A low-dose combination of xylazine $(0.5 \mathrm{mg} / \mathrm{kg}$ body weight $)$ and ketamine $(1 \mathrm{mg} / \mathrm{kg})$, delivered by intravenous injection, was used. Once anaesthesia was induced, 10 IU oxytocin were injected in the right jugular vein $1 \mathrm{~min}$ before the start of milking, in order to induce milk let-down. Total production of milk was computed as the mean production of two milkings multiplied by the time period between them, and then adding up the results for all milking periods ${ }^{(63)}$.

\section{Ethical note}

All sampling frequencies and handling procedures were designed to reduce stress for the animals, according to European and Spanish laws and current guidelines for ethical use of animals in research ${ }^{(64)}$. The experiment was approved by the University Ethical Committee of Universidad de Castilla-La Mancha.

\section{Statistical analysis}

Pearson correlations showed how the behavioural indices used (time and visits) correlated with total supplement consumption. Student's $t$ tests were used to assess differences between hinds and calves in behavioural indices of consumption (separately, mean intake visits and mean consumption time per individual; both in general and for every mineral compound). Similar Student's $t$ tests analysed the effect of calf sex in mean values per individual of the same variables. The same analysis showed differences between male and female calves in birth weight and gains during lactation, as well as differences between hinds rearing a male or a female in calving weight and milk production.

General linear model (GLM) analyses were performed on total intake visits and total consumption time per hind, in order to see the influence of age in overall mineral consumption relative to other physiological variables. In order to assess discrimination among different minerals, another set of GLM examined mean intake visits and time spent on each mineral per animal (coded as a categorical factor) relative to that of $\mathrm{NaCl}$. These sets of GLM (examining separately hinds and calves) also examined the effect of important lactation variables such as calf sex, age, total milk production, calving weight of mothers, and birth weight and gains of calves 


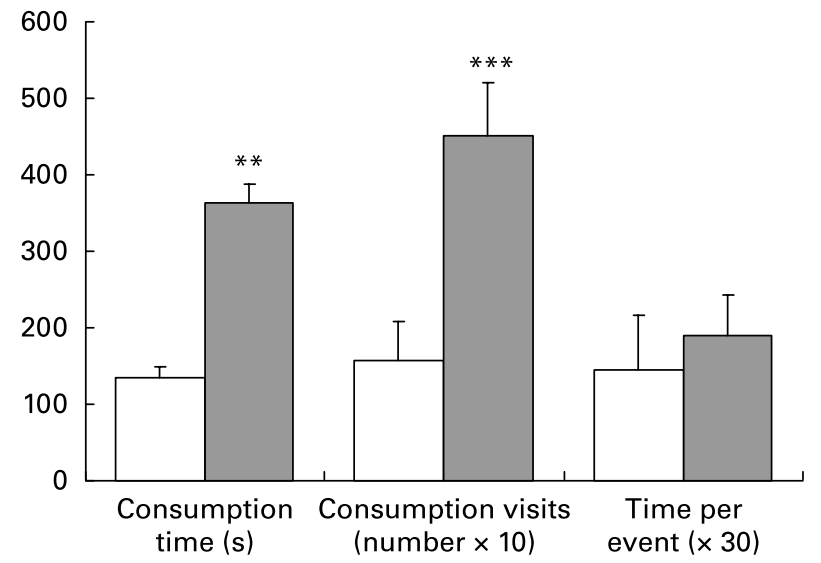

Fig. 1. Overall behavioural differences in consumption-related behaviours (time and frequency of intake visits; all minerals pooled), and time per event, between hinds $(\square)$ and calves ( $\square$ ). Values are means, with standard deviations represented by vertical bars. Mean value was significantly different from that for the hinds: ${ }^{\star \star} P<0.01$, ${ }^{\star \star \star} P<0.001$ (Student's $t$ test).

during lactation. Statistical analyses were performed using SPSS (version 15.0; SPSS, Inc., Chicago, IL, USA).

To assess the effect of social learning, we correlated the consumption time or frequency of visits of each hind and her calf towards each supplement separately. Because the data did not fit a normal distribution, we used non-parametric
Spearman correlations between behavioural indices of the mother and those of her calf.

\section{Results}

As the exact amount of mineral consumed in every visit could not be assessed, total consumption time (in s) and total intake visits were used as behavioural indices of consumption. These indices correlated significantly with total consumption $(\mathrm{g})$ of every supplement during every year of the experiment ( $n$ 21; consumption time, $R 0.79$; intake visits, $R$ 0.74; both $P<0 \cdot 001)$. Thus, they can be used as indices of actual mineral consumption.

\section{Age-related differences in mineral consumption}

Student's $t$ tests revealed overall differences in behavioural indices of mineral consumption between adult hinds and suckling calves (Fig. 1). Calves had a longer consumption time $(F(1,117)=7.67 ; P<0.01)$ and greater frequency of intake visits $(F(1,117)=17.7 ; \quad P<0.001)$ than their mothers. Mean time per visit was similar for hinds and calves. The same analysis exerted on each mineral showed differences between hinds and calves on mean consumption time for all mineral supplements, except $\mathrm{NaCl}$ (Fig. 2(a); parameters not shown for purposes of briefness). Similarly, there were
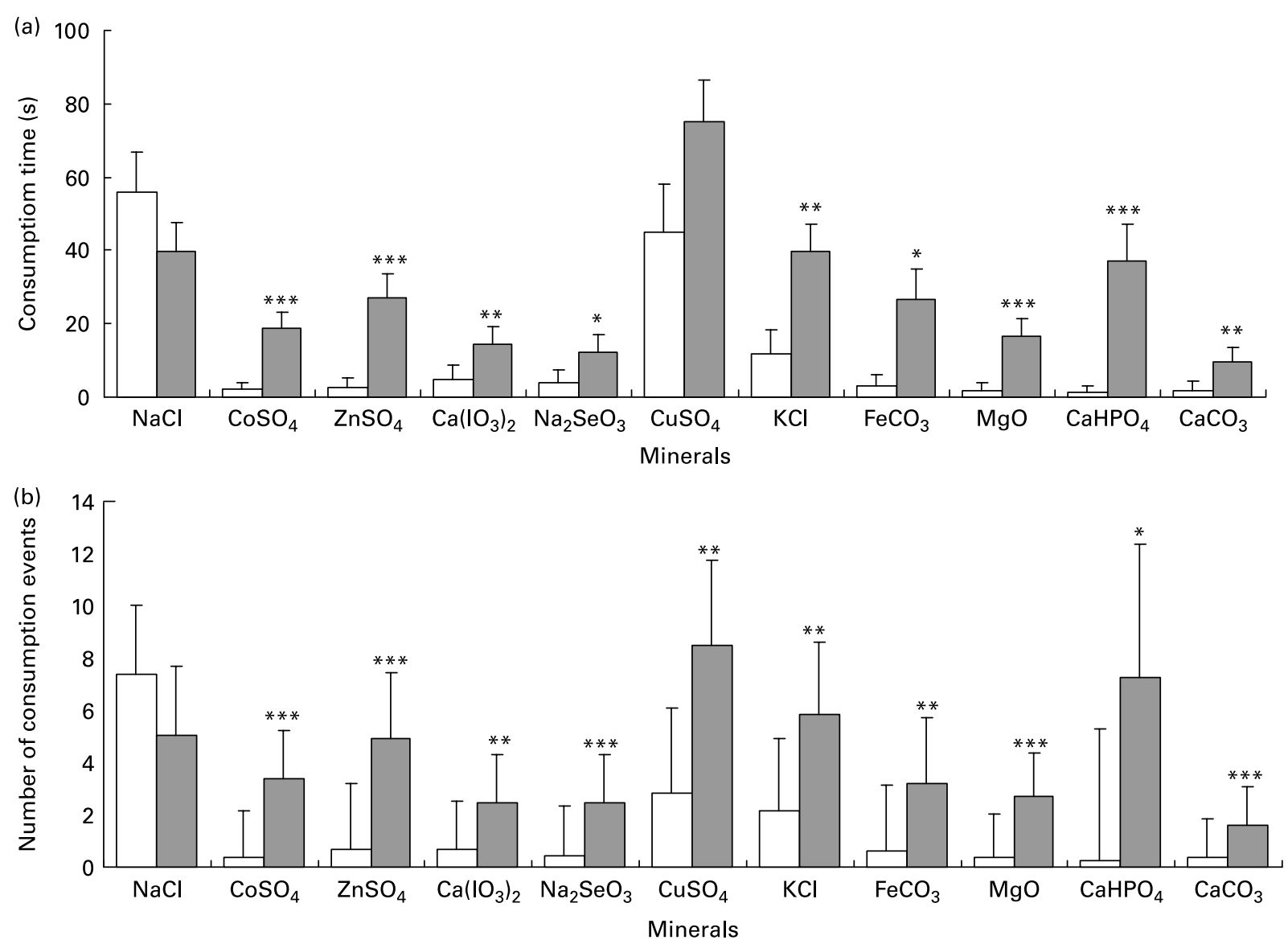

Fig. 2. Behavioural consumption differences between hinds ( $\square$ ) and calves ( $\square$ ) for every mineral offered in a cafeteria test. (a) Consumption time; (b) intake visits. Values are means, with standard deviations represented by vertical bars. Mean value was significantly different from that for the hinds: ${ }^{\star} P<0.05,{ }^{\star \star} P<0.01$, ${ }^{\star \star \star} P<0.001$ (Student's $t$ test). 
differences between hinds and calves on mean frequency of intake visits for all mineral supplements except $\mathrm{NaCl}$ and $\mathrm{CuSO}_{4}$ (Fig. 2(b)).

A GLM examining overall mineral consumption by hinds also showed the influence of age on total consumption time and frequency of intake visits. This age effect was only observed over intake visits (model $R^{2} 0.24 \%$; intercept, -37 (SD 32); calf sex, $15 \cdot 2$ (SD 7.4), $P=0.047$; calving weight, 0.90 (SD 0.37$), P=0.018$; total milk yield, (10 $($ SD 1$)) \times 10^{-3}, P=0.026$; age, -2.68 (SD 1.31), $P=0.046$; year was NS) but not over consumption time.

\section{Sex-related differences in mineral consumption}

Male and female calves showed similar consumption behaviour (Fig. 3(a) and (b)) except for $\mathrm{NaCl}$ (consumption time, $F(1,58)=4.26, P=0.044$; intake visits, $F(1,58)=5.40$, $P=0.024$ ) and $\mathrm{CaCO}_{3}$ (consumption time, $F(1,58)=6 \cdot 19$, $P=0 \cdot 016$; intake visits, $F(1,58)=5 \cdot 14, P=0 \cdot 027)$. Even if males have greater calf birth weight $(F(1,58)=14.44$; $P<0.001)$ and calf gains $(F(1,58)=47.06 ; P<0.001)$, there was no effect of sex on overall behavioural indices of consumption (Table 2), although indices were always greater for males than females. GLM models also showed a greater consumption time and intake visits by hinds rearing a male calf (Table 3), but there were no differences in calving weight $(F(1,58)=2 \cdot 38 ; \quad \mathrm{NS})$ and total milk yield $(F(1,43)=0 \cdot 93$; NS $)$.

\section{Mineral discrimination}

Two GLM tested the difference in consumption time and intake visits between minerals supplemented and the most consumed mineral $(\mathrm{NaCl})$, in addition to the influence of important physiological factors (Tables 2 and 3). For calves, the analysis showed indices of consumption similar to $\mathrm{NaCl}$ for all minerals supplemented, both in consumption time and intake visits, except a greater consumption of $\mathrm{CuSO}_{4}$, and a smaller consumption of $\mathrm{Na}_{2} \mathrm{SeO}_{3}$ (both mixed with salt) and $\mathrm{CaCO}_{3}$ (Table 2), therefore suggesting discrimination at least for these minerals. It also showed increased consumption in heavier calves, as well as differences between years. There was no influence of sex on consumption time or intake visits. Because $\mathrm{CaHPO}_{4}, \mathrm{CaCO}_{3}, \mathrm{FeCO}_{3}$ and $\mathrm{MgO}$ were offered unmixed with salt, additional models tested if hinds or calves discriminated among these pure, non-salty minerals using $\mathrm{CaCO}_{3}$ as a reference. These models revealed a different consumption pattern between $\mathrm{CaHPO}_{4}$ and $\mathrm{CaCO}_{3}$ (model for calves' consumption time: $R^{2} 0.07 \%$; calf birth weight $=12.7$ (SD 5.7), $P=0.028 ; \mathrm{CaHPO}_{4}=29.7$ (SD 11.7), $P=0.012$; NS terms: year, sex, calf gains, $\mathrm{FeCO}_{3}$ and $\mathrm{MgO}$. Model for calves' intake visits: $R^{2} 0.06 \%$; calf birth weight $=1.19$ (SD 0.60), $P=0.048 ; \mathrm{CaHPO}_{4}=2.87(\mathrm{SD} 1.23) ; P=0.020$;
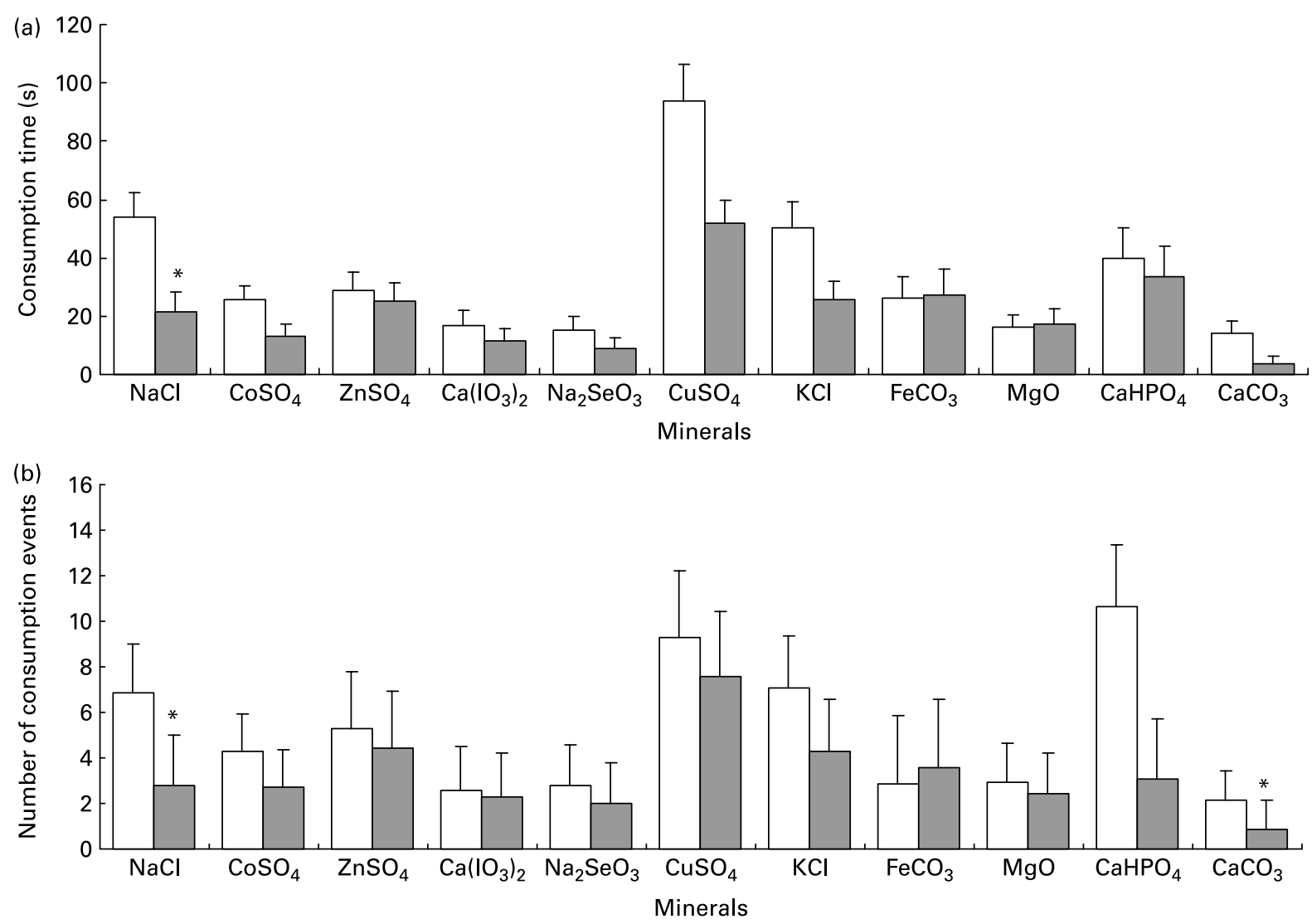

Fig. 3. Behavioural consumption differences between male ( $\square$ ) and female ( $\square$ ) calves for every mineral offered in a cafeteria test. (a) Consumption time; (b) intake visits. * Mean value was significantly different from that for the male calves $(P<0.05$; Student's $t$ test). 
Table 2. General linear models showing the influence of different mineral compounds and lactation variables on total consumption time and intake visits by lberian red deer (Cervus elaphus hispanicus) calves ( $n 59) \dagger$

(Mean values and standard deviations)

\begin{tabular}{|c|c|c|c|c|c|c|}
\hline \multirow[b]{3}{*}{ Factor } & \multicolumn{3}{|c|}{ Consumption time } & \multicolumn{3}{|c|}{ Intake visits } \\
\hline & \multicolumn{2}{|c|}{ Coefficient } & \multirow[b]{2}{*}{$P$} & \multicolumn{2}{|c|}{ Coefficient } & \multirow[b]{2}{*}{$P$} \\
\hline & Mean & SD & & Mean & SD & \\
\hline Intercept & -88 & 31 & & $-7 \cdot 2$ & $2 \cdot 2$ & \\
\hline$R^{2}$ & \multicolumn{2}{|c|}{$13.2 \%$} & \multicolumn{4}{|c|}{$13.1 \%$} \\
\hline Yearł & -14 & 5 & $0.012^{*}$ & -1.9 & 0.6 & $0.001^{* *}$ \\
\hline Sex & - & & - & - & & - \\
\hline Calf gain & - & & - & - & & - \\
\hline Calf birth weight & 164 & 4 & $<0.001^{\star * *}$ & - & & - \\
\hline Mineral§ & & & $<0.001^{\star \star \star}$ & & & $<0.001^{\star \star \star}$ \\
\hline Salt $+\mathrm{CoSO}_{4}$ & - & & - & - & & - \\
\hline Salt $+\mathrm{CuSO}_{4}$ & 40 & 12 & $0.001^{\star \star}$ & 4.0 & $1 \cdot 2$ & $0.001^{\star *}$ \\
\hline Salt $+\mathrm{Ca}\left(\mathrm{IO}_{3}\right)_{2}$ & - & & - & - & & - \\
\hline Salt $+\mathrm{Na}_{2} \mathrm{SeO}_{3}$ & -25 & 8 & $0.033^{*}$ & - & & - \\
\hline Salt $+\mathrm{ZnSO}_{4}$ & - & & - & - & & - \\
\hline $\mathrm{KCl}$ & - & & - & - & & - \\
\hline $\mathrm{FeCO}_{3}$ & - & & - & - & & - \\
\hline $\mathrm{MgO}$ & - & & - & - & & - \\
\hline $\mathrm{CaHPO}_{4}$ & - & & - & - & & - \\
\hline $\mathrm{CaCO}_{3}$ & -29 & 12 & $0.014^{*}$ & -3.3 & $1 \cdot 2$ & $0.009^{\star *}$ \\
\hline $\mathrm{NaCl}$ & Reference & & & Reference & & \\
\hline \multicolumn{7}{|c|}{ 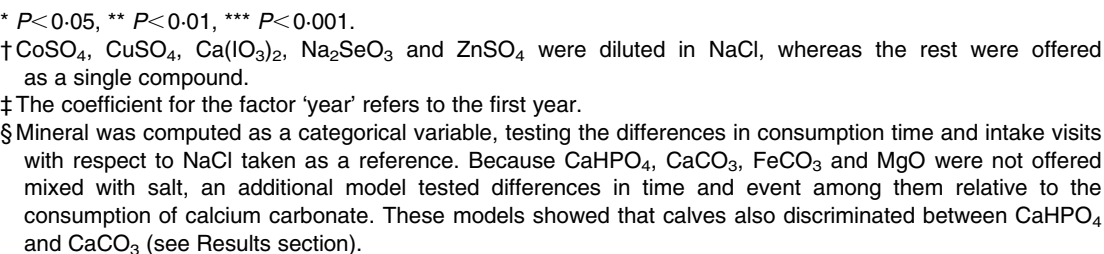 } \\
\hline
\end{tabular}

year, sex, calf gains, $\mathrm{FeCO}_{3}$ and $\mathrm{MgO}$ were $\mathrm{NS}$ ). This shows that calves discriminated not only between $\mathrm{NaCl}$ and saltmixed minerals $\left(\mathrm{CuSO}_{4}, \mathrm{Na}_{2} \mathrm{SeO}_{3}\right)$, but also among minerals not mixed with salt.

The same analysis on hinds revealed that all minerals supplemented (except consumption time of $\mathrm{CuSO}_{4}$ ) showed a different pattern compared with the reference mineral $(\mathrm{NaCl})$. The models also showed a greater consumption by younger hinds and hinds rearing heavier calves, in addition to a greater consumption time and intake visits by hinds having a male calf and those producing less milk. Models testing discrimination among unmixed supplements showed lack of differences both in consumption time and intake visits. Thus, the only evidence of mineral discrimination by hinds relates to $\mathrm{NaCl}$ and $\mathrm{CuSO}_{4}$ against all other minerals.

\section{Social learning and mineral consumption}

Table 4 shows the correlation between the time or frequency of visits of the calf and those of the mother for the fiftynine pairs of hinds-calves (twenty-three in the case of Co). The results show that there was a social learning effect, i.e. the calf was more likely to consume the mineral if the mother consumed it, for those minerals that were mixed with salt $(\mathrm{Co}, \mathrm{Cu}, \mathrm{I}, \mathrm{Zn}, \mathrm{Se}$ and $\mathrm{Na})$, but calves consumed those minerals not mixed with salt irrespective of the consumption behaviour of their mothers.

\section{Discussion}

Results suggest that deer seem to discriminate between minerals even if they are mixed with a palatable excipient with a strong flavour such as sodium salt, but also among palatable mineral supplements not mixed with salt. In addition, calves showed behavioural indices of consumption greater than their mothers even though both showed a similar mean time per visit. Because both visits and time correlated with the actual consumption of mineral supplements, the former differences suggest greater mineral consumption by calves compared with hinds. Consumption in response to palatability should produce greater intake by larger hinds and larger calves, as found here, but also a much greater consumption by hinds with respect to calves. Thus, differences between calves and hinds may reflect a greater consumption behaviour based on the greater physiological demands of growth ${ }^{(15,16)}$, while results found within calves and hinds are also compatible with greater demands as weight increases ${ }^{(14-16)}$. The effect is not independent of behavioural influences such as social learning in calves watching their mothers, but this was only found for minerals mixed with salt, whereas calves consumed minerals not mixed with salt even though their mothers did not consume them.

Several studies have shown differences in mineral consumption related to sex and age, but always within adults or yearlings ${ }^{(21,22,65,66)}$. In contrast, mineral consumption by young calves has been scarcely reported. Hinds consumed mainly $\mathrm{NaCl}$ and $\mathrm{CuSO}_{4}$ (mixed with salt), but not other 
Table 3. General linear models showing the influence of different mineral compounds and lactation variables on total consumption time and intake visits by Iberian red deer (Cervus elaphus hispanicus) hinds ( $n$ 59) $\dagger$

(Mean values and standard deviations)

\begin{tabular}{|c|c|c|c|c|c|c|}
\hline \multirow[b]{3}{*}{ Factor } & \multicolumn{3}{|c|}{ Consumption time } & \multicolumn{3}{|c|}{ Intake visits } \\
\hline & \multicolumn{2}{|c|}{ Coefficient } & \multirow[b]{2}{*}{$P$} & \multicolumn{2}{|c|}{ Coefficient } & \multirow[b]{2}{*}{$P$} \\
\hline & Mean & SD & & Mean & SD & \\
\hline Intercept & 71 & 16 & & 1.6 & $2 \cdot 7$ & \\
\hline$R^{2}$ & \multicolumn{2}{|c|}{$12 \cdot 8 \%$} & & \multicolumn{2}{|c|}{$9.4 \%$} & \\
\hline Year & - & - & - & - & - & - \\
\hline Calf sex & 15 & 7 & $0.032^{*}$ & 1.5 & 0.6 & $0.015^{\star}$ \\
\hline Age & - & - & - & -0.26 & 0.11 & $0.015^{\star}$ \\
\hline Total milk yield & -0.001 & 0.000 & $0.030^{*}$ & $-6.5 \times 10^{-5}$ & $0.1 \times 10^{-5}$ & $0.007^{\star \star}$ \\
\hline Calving weight & - & - & - & 0.086 & 0.029 & $0.003^{\star *}$ \\
\hline Mineralł & & & $<0.001^{\star \star \star}$ & & & $<0.001^{\star \star \star}$ \\
\hline Salt $+\mathrm{CoSO}_{4}$ & -54 & 19 & $0.005^{\star *}$ & $-6 \cdot 6$ & 1.6 & $<0.001^{* * *}$ \\
\hline Salt $+\mathrm{CuSO}_{4}$ & - & - & - & $-3 \cdot 0$ & $1 \cdot 3$ & $0.021^{\star}$ \\
\hline Salt $+\mathrm{Ca}\left(\mathrm{IO}_{3}\right)_{2}$ & -49 & 16 & $0.002^{\star \star}$ & -6.0 & $1 \cdot 3$ & $<0.001^{\star \star \star}$ \\
\hline Salt $+\mathrm{Na}_{2} \mathrm{SeO}_{3}$ & -39 & 16 & $0.013^{\star}$ & $-6 \cdot 3$ & 1.3 & $<0.001^{\star \star \star}$ \\
\hline Salt $+\mathrm{ZnSO}_{4}$ & -50 & 16 & $0.002^{* *}$ & -6.0 & $1 \cdot 3$ & $<0.001^{\star \star \star}$ \\
\hline $\mathrm{KCl}$ & -51 & 16 & $0.001^{\star *}$ & $-4 \cdot 1$ & 1.3 & $0.002^{\star \star}$ \\
\hline $\mathrm{FeCO}_{3}$ & -51 & 16 & $0.001^{* *}$ & $-6 \cdot 1$ & $1 \cdot 3$ & $<0.001^{\star * *}$ \\
\hline $\mathrm{MgO}$ & -53 & 16 & $0.001^{\star *}$ & -6.4 & $1 \cdot 3$ & $<0.001^{\star \star \star}$ \\
\hline $\mathrm{CaHPO}_{4}$ & -54 & 16 & $0.001^{\star \star}$ & -6.5 & 1.3 & $<0.001^{\star \star \star}$ \\
\hline $\mathrm{CaCO}_{3}$ & -53 & 16 & $0.001^{* *}$ & -6.5 & 1.3 & $<0.001^{* * *}$ \\
\hline $\mathrm{NaCl}$ & Reference & & & Reference & & \\
\hline
\end{tabular}

${ }^{\star} P<0.05,{ }^{* *} P<0.01,{ }^{* * *} P<0.001$.

$+\mathrm{CoSO}_{4}, \mathrm{CuSO}_{4}, \mathrm{Ca}\left(\mathrm{IO}_{3}\right)_{2}, \mathrm{Na}_{2} \mathrm{SeO}_{3}$ and $\mathrm{ZnSO}_{4}$ were diluted in $\mathrm{NaCl}$, whereas the rest were offered as a single compound.

$\ddagger$ Mineral was computed as a categorical variable, testing the differences in consumption time and intake visits with respect to $\mathrm{NaCl}$ taken as a reference. Because $\mathrm{CaHPO}_{4}, \mathrm{CaCO}_{3}, \mathrm{FeCO}_{3}$ and $\mathrm{MgO}$ were not offered mixed with salt, an additional model tested differences in time and event among them relative to the consumption of calcium carbonate. These models showed the same results.

microminerals supplemented even though they had a very similar salted flavour $\left(\mathrm{KCl}\right.$ and salt-mixed minerals $\mathrm{CoSO}_{4}$, $\left.\mathrm{Ca}\left(\mathrm{IO}_{3}\right)_{2}, \mathrm{Na}_{2} \mathrm{SeO}_{3}, \mathrm{ZnSO}_{4}\right)$. This is particularly striking for the case of $\mathrm{KCl}$, which has a very similar salty flavour to the human taste. In contrast, consumption by calves was more balanced among all supplements. However, despite this, $\mathrm{Cu}$, which is one of the most important trace minerals involved in growth ${ }^{(16,51,67)}$, was apparently consumed in greater quantities. The suggestion that growth imposes greater needs of mineral consumption also seems to explain the consumption by calves of $\mathrm{NaCl}$ mixed with trace minerals which hinds did not consume. Moreover, among hinds greater behavioural indices of consumption were observed in younger ones, reflecting the additional effect of still-growing animals on the needs imposed by lactation ${ }^{(68)}$. In contrast, if intake depends on palatability larger animals with larger bodies should consume more and, thus, hinds should consume greater amounts of minerals than calves. A further argument against intake driven by palatability is that preference of minerals was different for calves and hinds, whilst the same pattern for all of them should be predicted by palatability.

As previously indicated, conditioned learning seems to be the most accepted mechanism underlying diet selection but most of the assumptions of this model seem hard to apply to free-ranging ruminants because learning fails when experimental settings include both positive and negative cues or mixtures of different foods (as usually happens in the wild $\left.^{(33,44)}\right)$. Conditioned learning seems to be an appropriate and simple way of learning a one-way effect: always positive or negative. However, minerals show decreasing positive effects with increasing intake within deficiency up to a certain range when they have a neutral effect, and increasing negative effects afterwards. In cases such as Se, the range between positive effects and toxicity is a very narrow one ${ }^{(16)}$. Thus, conditioned learning may be much more ineffective than innate ability to ingest minerals depending on relative requirements. One reason for this is that in the complex system of diet selection by ungulates, a quick and accurate provision of balanced nutrients should be much more important than a slow process of learning the properties of foods ${ }^{(46)}$. In addition, many assumptions of the conditioned learning model do not fit to the present experiment as there is no

Table 4. Correlation coefficients between consumption time or events by the calf and those by their mothers

\begin{tabular}{|c|c|c|c|c|c|}
\hline & \multirow[b]{2}{*}{$\begin{array}{c}\text { Animals } \\
(n)\end{array}$} & \multicolumn{2}{|c|}{ Events } & \multicolumn{2}{|c|}{ Time } \\
\hline & & $\begin{array}{c}\text { Spearman's } \\
\rho\end{array}$ & $P$ & $\begin{array}{c}\text { Spearman's } \\
\rho\end{array}$ & $P$ \\
\hline Total & 59 & 0.203 & NS & 0.207 & NS \\
\hline $\mathrm{CaCO}_{3}$ & 59 & 0.140 & NS & 0.167 & NS \\
\hline Co & 23 & 0.397 & NS & 0.467 & 0.025 \\
\hline $\mathrm{Cu}$ & 59 & 0.346 & 0.007 & 0.332 & 0010 \\
\hline $\mathrm{Fe}$ & 59 & 0.126 & NS & 0.109 & NS \\
\hline I & 59 & 0.487 & 0.000 & 0.467 & 0.000 \\
\hline $\mathrm{K}$ & 59 & 0.219 & NS & 0.257 & 0.050 \\
\hline $\mathrm{Mg}$ & 59 & -0.009 & NS & 0.049 & NS \\
\hline $\mathrm{Na}$ & 59 & 0.304 & 0.019 & 0.333 & 0.010 \\
\hline $\mathrm{CaHPO}_{4}$ & 59 & 0.076 & NS & 0.066 & NS \\
\hline $\mathrm{Se}$ & 59 & 0.362 & 0.005 & 0.306 & 0.019 \\
\hline $\mathrm{Zn}$ & 59 & 0.382 & 0.003 & 0.366 & 0.004 \\
\hline
\end{tabular}


previous learning, several similar flavours correspond to different mineral contents, and animals frequently ate from more than one supplement on every visit.

Thus, our evidence suggests that deer are capable of discriminating minerals beyond evidence published for $\mathrm{Na}$ and $\mathrm{P}^{(15,16,31)}$. This also seems to be the first published evidence that animals can detect small amounts of microminerals even within a homogeneous strong flavour such as salt (for human subjects, see Epke \& Lawless $\left.{ }^{(69)}\right)$. In addition, results suggest that discriminating behaviour probably reflects physiological requirements for some of them (as also was previously published ${ }^{(26)}$ ), especially because the pattern observed was different for calves and hinds, whilst palatability predicts the same for both. Thus, for example, hinds showed low levels of behavioural indices of consumption for all minerals supplemented except $\mathrm{NaCl}$, which was the most actively sought. This may reflect the fact that milk production is constrained by $\mathrm{Na}^{(70)}$. Behavioural indices of consumption for calves were similarly high for most salt-flavoured supplements (except a higher one for $\mathrm{CuSO}_{4}$ and a reduced intake of $\mathrm{Na}_{2} \mathrm{SeO}_{3}$ ). In addition, consumption indices for $\mathrm{CaHPO}_{4}$ were greater than those for $\mathrm{CaCO}_{3}$. Chládek \& Zapletal ${ }^{(71)}$ showed how cows control the $\mathrm{Ca}: \mathrm{P}$ ratio by choosing between different mineral blocks independently of $\mathrm{Na}$ content, and similar results were obtained by Villalba et al. ${ }^{(27)}$. Because $\mathrm{Ca}$ and $\mathrm{P}$ are the main elements of bone but calcium carbonate also has $\mathrm{Ca}$, the behaviour observed also supports the idea that animals have evolved the ability to discriminate among these minerals as an attempt to meet diet requirements. Male calves showed an intake of $\mathrm{NaCl}$ and $\mathrm{CaCO}_{3}$ greater than that of females, and hinds' consumption for most minerals also depended on having a male or a female calf. That is coherent with previous findings by our research group that show differences in milk mineral composition related to the sex of the calf $^{(72)}$, which suggests both a sex effect on calf mineral requirements and a different physiological effort for milk mineral production of mothers of males compared with mothers of females.

In conclusion, sex- and age-related differences were found in behavioural indices of mineral consumption in Iberian red deer hinds and calves. These differences show discrimination of essential minerals in a different pattern for calves and hinds. Both the greater consumption by calves and the different preference for calves and hinds suggest that deer do not discriminate and consume based on palatability. Results suggest that behavioural indices of consumption may respond to physiological needs, and thus they might support the existence of discrimination mechanisms that may make possible that deer select a balanced mineral diet. However, further experiments are needed to fully prove that red deer behave as optimal foragers of trace minerals, i.e. showing if animals respond to inflicted specific trace-mineral deficiencies by adjusting intake of them, as recently shown for $\mathrm{Se}$ consumption by hens ${ }^{(73)}$.

\section{Acknowledgements}

The authors wish to thank Enrique Gaspar-Lopez, Debora Carrión, Cesar Augusto Olguín, Fulgencio Cebrián, Bernardo Albiñana and Isidoro Cambronero for their help with data collection and animal handling. The present study was supported by projects CGL2008-00749/BOS (Ministerio de Ciencia e Innovación-Fondo Europeo de Desarrollo Regional) and PC108-0115 (Junta de Comunidades de Castilla-La Mancha).

T. L.-C., A. J. G. and L. G designed the original trial; F. C., A. J. G. and J. A. E. participated in data collection; L. G. and T. L.-C. obtained funding; F. C. and T. L.-C. undertook the statistical analyses and wrote the first draft of the manuscript. All authors approved the final manuscript.

All authors declared that they had no conflict of interest.

\section{References}

1. Emlen JM (1966) The role of time and energy in food preferences. Am Nat 100, 611-617.

2. McArthur RH \& Pianka E (1966) On optimal use of a patchy environment. Am Nat 100, 603-609.

3. Stephens DW \& Krebs JR (1986) Foraging Theory. Princeton, NJ: Princeton University Press.

4. Wilmshurst JF, Fryxell JM \& Hudson RJ (1995) Forage quality and patch choice by wapiti (Cervus elaphus). Behav Ecol 6, 209-217.

5. Wilmshurst JF, Fryxell JM \& Colucci PE (1999) What constrains daily intake in Thomson's gazelles? Ecology 80, 2338-2347.

6. Hessle A, Rutter M \& Wallin K (2008) Effect of breed, season and pasture moisture gradient on foraging behaviour in cattle on semi-natural grasslands. Appl Anim Behav Sci 111, 108-119.

7. Owen-Smith N \& Novellie P (1982) What should a clever ungulate eat? Am Nat 119, 151-178.

8. Ackroff K (1992) Foraging for macronutrients: effects of protein availability and abundance. Physiol Behav 51, 533-542.

9. Westoby M (1974) An analysis of diet selection by large generalist herbivores. Am Nat 108, 290-304.

10. Harborne JB (1982) Introduction to Ecological Biochemistry. London: Academic Press.

11. Hughes RN (1993) Diet Selection: An Interdisciplinary Approach to Foraging Behaviour. Cambridge, MA: Blackwell Scientific Publications.

12. Belovsky GE (1978) Diet optimization in a generalist herbivore: the moose. Theor Popul Biol 14, 105-134.

13. Botkin DB, Jordan PA, Dominsky AS, et al. (1973) Sodium dynamics in a northern ecosystem. Proc Natl Acad Sci U S A 70, 2745-2748.

14. Hellgren EC \& Pitts WJ (1997) Sodium economy in white-tailed deer (Odoicoleus virginianus). Physiol Zool 70, 547-555.

15. McDowell LR (1996) Feeding minerals to cattle on pasture. Anim Feed Sci Technol 60, 247-271.

16. McDowell LR (2003) Minerals in Animal and Human Nutrition. Amsterdam: Elsevier.

17. McNaughton SJ (1988) Mineral nutrition and spatial concentrations of African ungulates. Nature 334, 343-345.

18. McNaughton SJ (1990) Mineral nutrition and seasonal movements of African migratory ungulates. Nature 345, 613-615.

19. Seagle SW \& McNaughton SJ (1992) Spatial variation in forage nutrient concentrations and the distribution of Serengeti grazing ungulates. Landscape Ecol 70, 229-241.

20. Tracy BF \& McNaughton SJ (1995) Elemental analysis of mineral lick soils from the Serengeti National Park, the Konza Prairie and Yellowstone National Park. Ecography 18, 91-94.

21. Atwood TC \& Weeks HP (2002) Sex- and age-specific patterns of mineral lick use by white-tailed deer (Odocoileus virginianus). Am Midl Nat 148, 289-296. 
22. Barrows GT (1977) Research efforts have lagged in free-choice feeding. Anim Nutr Health 32, 12-14.

23. Ben-Shahar R \& Coe MJ (1992) The relationship between soil factors, grass nutrients and the foraging behaviour of wildebeest and zebra. Oecologia 90, 422-428.

24. Richter CP (1943) Total self-regulatory functions in animals and human beings. Harvey Lect 38, 63-103.

25. Fielder PC (1986) Implications of selenium levels in Washington mountain goats, mule deer, and Rocky Mountain elk. Northwest Sci 60, 15-20.

26. Ceacero F, Landete-Castillejos T, García AJ, et al. (2009) Free-choice mineral consumption in Iberian red deer (Cervus elaphus hispanicus) response to diet deficiencies. Livest Sci 122, 345-348.

27. Villalba JJ, Provenza FD \& Hall JO (2008) Learned appetites for calcium, phosphorus, and sodium in sheep. J Anim Sci 86, $738-747$.

28. Kyriazakis I, Tolkamp BJ \& Emmans G (1999) Diet selection and animal state: an integrative framework. Proc Nutr Soc 58, 765-772.

29. Provenza FD (1995) Postingestive feedback as an elementary determinant of food preference and intake in ruminants. $J$ Range Manage 48, 2-17.

30. McDowell LR (1985) Nutrition of Grazing Ruminants in Warm Climates. New York: Academic Press.

31. Muller LD, Schaffer LV, Ham LC, et al. (1977) Cafeteria-style free-choice mineral feeder for lactating dairy cows. J Dairy Sci 60, $1574-1582$.

32. Tait RM \& Fisher LJ (1996) Variability in individual animal's intake of minerals offered free-choice to grazing ruminants. Anim Feed Sci Technol 62, 69-76.

33. Duncan AJ \& Young SA (2002) Can goats learn about foods through conditioned food aversions and preferences when multiple food options are simultaneously available? J Anim Sci 80, 2091-2098.

34. Kissileff HR (1991) Chance and necessity in ingestive behaviour. Appetite 14, 1-22.

35. Sclafani A (1991) Conditioned food preferences. B Psychonomic Soc 29, 256-260.

36. Provenza FD, Burritt EA, Clausen TP, et al. (1990) Conditioned flavour aversion: a mechanism for goats to avoid condensed tannins in blackbrush. Am Nat 136, 810-828.

37. Jansen DAWAM, van Langevelde F, de Boer WF, et al. (2007) Optimisation or satiation, testing diet selection rules in goats. Small Rumin Res 73, 160-168.

38. Kronberg SL, Muntifering RB \& Ayers EL (1993) Feed aversion learning in cattle with delayed negative consequences. J Anim Sci 71, 1767-1770.

39. Kyriazakis I, Papachristou TG, Duncan AJ, et al. (1997) Mild conditioned food aversions developed by sheep towards flavours associated with plant secondary compounds. J Chem Ecol 23, 727-746.

40. Arnold GW (1981) Grazing behaviour. Grazing Animals, pp. 79-104 [FW Morley, editor]. Amsterdam: Elsevier.

41. Villalba JJ \& Provenza FD (1997) Preference for flavored wheat straw by lambs conditioned with intraruminal infusions of acetate and propionate. J Anim Sci 75, 2905-2914.

42. Ginane C, Duncan AJ, Young SA, et al. (2005) Herbivore diet selection in response to simulated variation in nutrient rewards and plant secondary compounds. Anim Behav 69, 541-550.

43. Sclafani A (1997) Learned controls of ingestive behaviour. Appetite 29, 153-158.

44. Duncan AJ, Elwert C, Villalba JJ, et al. (2007) How does pattern of feeding and rate of nutrient delivery influence conditioned food preferences? Oecologia 153, $617-624$.
45. van Wieren SE (1996) Do large herbivores select a diet that maximizes short-term energy intake rate? Forest Ecol Manage 88, 149-156.

46. Yearsley J, Villalba JJ, Gordon IJ, et al. (2006) A theory of associating food types with their post-ingestive effects. Am Nat 167, 705-716.

47. Duncan AJ, Ginane C, Elston DA, et al. (2006) How do herbivores trade-off the positive and negative consequences of diet selection decisions? Anim Behav 71, 93-99.

48. Zahorik DM \& Houpt KA (1977) The concept of nutritional wisdom: applicability of laboratory learning models to large herbivores. In Learning Mechanisms in Food Selection, pp. 45-67 [LM Barker, M Best and M Domjan, editors]. Waco: Baylor University Press.

49. Zahorik DM \& Houpt KA (1981) Species differences in feeding strategies, food hazards and the ability to learn food aversions. In Foraging Behavior, pp. 289-310 [AC Kamil and TD Sargent, editors]. New York: Garland.

50. Bergvall UA (2009) Development of feeding selectivity and consistency in food choice over 5 years in fallow deer. Behav Process 80, 140-146.

51. Paik I (2001) Application of chelated minerals in animal production. Asian Austral J Anim 14, 191-198.

52. Llorens $\mathbf{J}$ (2004) The physiology of taste and smell: how and why we sense flavours. Water Sci Technol 49, 1-10.

53. Ingvartsen KL (1994) Models of voluntary food intake in cattle. Livest Prod Sci 39, 19-38.

54. West DB \& York B (1998) Dietary fat, genetic predisposition, and obesity: lessons from animal models. Am J Clin Nutr 67, 505S-512S.

55. Lieberman LS (2006) Evolutionary and anthropological perspectives on optimal foraging in obesogenic environments. Appetite 47, 3-9.

56. Thornton A \& Raihani NJ (2008) The evolution of teaching. Anim Behav 75, 1823-1836.

57. Landete-Castillejos T, García AJ, Garde JJ, et al. (2000) Milk intake and production curves and allosuckling in captive Iberian red deer, Cervus elaphus hispanicus. Anim Behav 60, 679-687.

58. Brelurut A, Pingard A \& Thériez M (1990) Le Cerf et son Élevage (The Stag and its Breeding). Paris: INRA.

59. Ward M \& Lardy G (2005) Beef Cattle Mineral Nutrition. North Dakota: NDSU Extension Service.

60. Arthington JD (2002) Essential Trace Minerals for Grazing Cattle in Florida. Gainesville, FL: University of Florida.

61. Blaxter KL, Kay RNB, Sharman GAM, et al. (1988) Farming the Red Deer. Edinburgh: H.M. Stationery Office for the Department of Agriculture and Fisheries for Scotland.

62. Gallego L, Landete-Castillejos T, García AJ, et al. (2006) Seasonal and lactational changes in mineral composition of milk from Iberian red deer (Cervus elaphus hispanicus). J Dairy Sci 89, 589-595.

63. Landete-Castillejos T, García AJ, Molina P, et al. (2000) Milk production and composition in captive Iberian red deer (Cervus elaphus hispanicus): effect of birth date. J Anim Sci 78, 2771-2777.

64. Association for the Study of Animal Behaviour (2008) Guidelines for the treatment of animals in behavioural research and teaching. Anim Behav 75, II-IX.

65. Atwood TC \& Weeks HP (2003) Sex-specific patterns of mineral lick preference in white-tailed deer. Northeast Nat 10, 409-414.

66. Best DA, Lynch GM \& Rongstad OJ (1977) Annual spring movements of moose to mineral licks in Swan Hills Alberta. Trans N Am Moose Conf Workshop 13, 215-228.

67. Bartoskewitz ML, Hewitt DG, Laurenz JC, et al. (2007) Effect of dietary copper and zinc concentrations on white-tailed deer 
antler growth, body size, and immune system function. Small Ruminant Res 73, 87-94.

68. Carrión D, García AJ, Gaspar-López E, et al. (2008) Development of body condition in hinds of Iberian red deer during gestation and its effects on calf birth weight and milk production. J Exp Zool 309A 1-10.

69. Epke EM \& Lawless HT (2007) Retronasal smell and detection thresholds of iron and copper salts. Physiol Behav 92, 487-491.

70. Pletscher DH (1987) Nutrient budgets for white-tailed deer in New England with special reference to sodium. J Mammal 68, 330-336.
71. Chládek G \& Zapletal D (2007) A free-choice intake of mineral blocks in beef cows during the grazing season and in winter. Livest Sci 106, 41-46.

72. Gallego L, Gomez JA, Landete-Castillejos T, et al. (2009) Effect of milk minerals on calf gains and sex differences in mineral composition of milk from Iberian red deer (Cervus elaphus hispanicus). Reproduction (epublication ahead of print version 5 August 2009).

73. Zuberbuehler CA, Messikommer RE \& Wenk C (2007) Choice feeding of selenium-deficient laying hens affects diet selection, selenium intake and body weight. J Nutr 132, 3411-3417. 